\title{
A Probe into the Ways of Improving Teaching Efficiency in Higher Vocational Schools
}

\author{
$\mathrm{NaCao}$ \\ Tianjin Maritime College, Office of Teaching Affairs, 300350
}

\begin{abstract}
Innovation is the source of social progress and it is a concentrated expression of the spirit at the knowledge economy times. The ever-increasing economic construction and social development speed make our higher vocational colleges face enormous challenges and golden opportunity. Facing the new education situation, deepening the teaching reform, accelerating the teaching management innovation and improving the overall teaching level and the quality of personnel training have become the urgent tasks to be solved in the current higher vocational education reform. This paper analyzes the status quo of the teaching management in higher vocational colleges and the necessity of improving the present situation and puts forward some thoughts on the teaching management of higher vocational colleges, aiming at promoting the development of higher vocational education better and faster.
\end{abstract}

Keywords: probe, improving teaching efficiency, higher vocational schools

\section{Introduction}

The mode of higher vocational education is diversified, the level of running schools is rich, and the operating mechanism is flexible. It has rich connotation in teaching organization form, institution setting type, organization development and historical evolution. It is an important part of higher education system. Education and economic and social development are closely linked, by the world's governments and the education sector attaches great importance. The basic task of teaching management in colleges and universities is to study teaching and management rules, improve teaching management, improve 
teaching management level; establish a stable teaching order to ensure the normal operation of teaching; research and organize the implementation of teaching reform; efforts to mobilize teachers and students to teach And teaching enthusiasm, teaching management in the management of colleges and universities occupy a particularly important position. The teaching management in higher vocational colleges is the most complicated management in school management. It is a multi - function, multi - factor, complex structure and comprehensive system. The central position of teaching determines the importance and particularity of teaching management in higher vocational colleges. At present, we must actively study and explore the innovation of teaching management in higher vocational colleges according to the development of the situation so as to enhance the quality of teaching and personnel training in vocational colleges.

\section{The Concept of Vocational Colleges}

Higher vocational colleges, is the abbreviation of higher vocational colleges, colleges and universities is an important part. From a global perspective, higher vocational education is a new type of higher education which appears at a certain stage of economic and social development. It is another type of higher education which is different from traditional ordinary higher education. It is based on the cultivation of higher education with certain theoretical knowledge and Oriented, technical-oriented and technical-oriented talents who are oriented to the grassroots level, oriented to the production, service-oriented and management first-line professional positions. Higher education is the advanced stage of vocational and technical education.

\section{The Main Problems of Teaching Management in Higher Vocational Colleges}

\subsection{Teaching management philosophy is lagging behind}

Higher vocational colleges, the predecessor of the development of better secondary vocational schools, in the teaching management and more follow the previous management. Teaching management philosophy is relatively backward, the lack of modern management awareness and way of thinking, empiricism, dogmatism is still prevalent, the executive order is still the main means of teaching managers, ignoring the teacher in teaching the dominant position, leading to teacher teaching initiative and creativity is suppressed, teaching behaviour and effectiveness and management of the difference between the target value increases. 


\subsection{The quality of teaching management team is uneven}

The quality of teaching management team affects the overall level of teaching management at a large extent. At present, the overall quality of teaching management personnel in vocational colleges varies, there are some age structure is too large, reform and innovation awareness and ability is weak; some non-firstline teachers, lack of necessary education and teaching theory, Unreasonable, continuing education and training is not sufficient to enhance the overall quality of difficulties.

\subsection{Teaching management assessment methods are outdated}

With the improvement of educational philosophy and teaching objectives, teaching management assessment system should be appropriately improved to meet the needs of development. The assessment of teaching management in vocational colleges is often one-way assessment, that is, by the senior management down to the assessment, the assessment can only be passed up the assessment information, which led to the lack of feedback assessment system is not conducive to the assessment work The objective and impartial, directly affects the quality of teaching management and development level.

\section{The Necessity of Strengthening Teaching Management in Higher Vocational Colleges}

\subsection{The inevitable demand of adapting to the development of higher vocational education}

With the development of science and technology and the popularization of higher education, the teaching management of higher vocational colleges is confronted with many new challenges: First, the expansion of higher vocational scale will bring new ideas to traditional teaching ideas and teaching modes. The second is the process of popularization of higher education on the quality of teaching and teaching management staff put forward higher requirements; third is due to the diversity of teaching objects and teaching needs of the ever-changing, the objective requirements to strengthen teaching management.

\subsection{The necessity of cultivating high quality innovative talents}

Cultivating high - quality innovative talents is a hot topic in the society. The ultimate goal of higher vocational education is to strengthen quality education and innovation education, respect the students' subject consciousness, develop students' potential, develop students' personality and cultivate innovative talents. This will inevitably require innovative teaching management, and actively explore and implement a more flexible and more flexible teaching management 
system, improve the quality of teaching management, improve the teaching mechanism, to cultivate innovative quality as the core of integrated talents.

\subsection{The necessity of deepening the higher vocational education reform}

In order to meet the needs of social development, higher vocational colleges have intensified the teaching reform and pushed forward and developed in depth. This requires that the teaching management of higher vocational colleges should be changed accordingly, and actively explore the innovative ways and measures of teaching management, To establish a fully mobilize the enthusiasm of teachers and students to teach and learn to promote the rapid development of higher vocational teaching management system and operational mechanisms to work creatively to promote the in-depth development of teaching reform, and continuously improve the level of service to the needs of the community.

\section{Suggestions on the Teaching Management Innovation of Higher Vocational Colleges}

\subsection{Adhere to the times, innovative teaching management philosophy}

The innovation of teaching management is the innovation of teaching management. The focus of teaching management should be to improve the students' comprehensive quality. Therefore, the urgent task of the innovation of teaching management in higher vocational education is to break the traditional teaching management idea, to change the closed view of teaching management into an open, socialized view of teaching management, by the standardization of teaching management Students will learn to learn and learn to create the concept of teaching management, teaching more emphasis on respect for the development of students' personality, classification guidance, individualized, independent learning for students, personality development and practical activities to provide more and more time and space, To cultivate innovative talents to meet the needs of society.

\subsection{Reshape the teaching management process}

For the teaching management system of vocational colleges, reshaping the teaching management process is the process of phased diagnosis, re-design and re-innovation of the teaching management at this stage. Analysis and reengineering of the teaching management process will directly lead to the reorganization of teaching management organizational structure. In the traditional teaching management system, the school management organization structure is the pyramid administrative structure. 


\subsection{Comprehensively increase the quality of teaching management in higher vocational colleges}

The quantity and comprehensive quality of the teaching management team in colleges and universities influence and determine the level and development speed of the university teaching management to a certain extent. The innovation of contemporary teaching management is the main body of the management work - the teaching management personnel put forward higher requirements: the teaching management must have the education and management of the real ability, as well as dialectical thinking and systematic thinking ability, scientific decision-making ability; To study and explore the educational tasks and special laws of colleges and universities to create a unique school of thought and ideas to ensure that the healthy operation of the various systems within the university. Therefore, it is necessary to carry out the basic principles of socialism education. Therefore, the teaching management personnel can only update the knowledge, strengthen professional learning, understand the new public management philosophy, to adapt to the needs of the times, and creatively work to better serve the teaching.

\section{Conclusion}

Teaching management is a complex system. The reform of teaching management should focus on the reform of personnel training mode. The research content is very rich, involving a wide range, the workload is very large, at the same time, teaching management practice is strong, and it is closely related to the school discipline characteristics and their own traditions. The research should be closely integrated with the practice.

\section{References}

[1] $\mathrm{Wu}$ Wei. Thoughts on the innovation of teaching management in higher vocational colleges. Journal of Adult Education of Hubei University, 55(12), pp.68-70, 2011

[2] Wang Yi. On the construction of teaching management team in colleges and universities. Hulunbeier College, 8 (5), pp.87- 91, 20013

[3] Wang Chengfu, Li Ruidong. The reform and exploration of teaching management system in higher vocational colleges. Economic Management Forum, 12(10), pp. 18- 20, 2012

[4] Liu Lusheng, Pan Jianzhong. The reform and practice of teaching management mode in higher vocational colleges. Jiangxi Education and Research, 8(4), pp.85-87, 2014 